\title{
FACTORS AFFECTING THE MEDICATION ADHERENCE OF THE PATIENTS WHO ARE PRESCRIBED ANTIBIOTICS
}

\author{
Ufuk AKKAYA ${ }^{1}$, Hakan DEMIRCI ${ }^{2}$
}

${ }^{1}$ Gokcadir Family Health Center, Bursa, TURKEY

2 Department of Family Medicine, University of Health Sciences Turkey Bursa Yuksek Ihtisas Training and Research Hospital, Bursa, TURKEY

\section{ABSTRACT}

Aim: In this study, our aim is to investigate the antibiotics adherence of the patients who are prescribed antibiotics.

Methods: This study was conducted on 353 patients between age 18-75 who were prescribed antibiotic and who were registered to Bursa Nilufer 23 Nisan Family Health Center between dates October 2018September 2019, following the ethics committee approval. In order to collect data in this study, beside the medical history, Socio-demographic Data Form, Morisky Medication Adherence Scale and short version of European Health Literacy Scale which questioned their antibiotics adherence were applied to the patients.

Results: Medication utilization loyalty was detected significantly higher in the participants with high health literacy. The disease for which antibiotics were most frequently prescribed was upper respiratory infection (32.3\%). It was followed by lower respiratory infections (23.5\%), acute sinusitis (13\%) and urinary tract infections (7.6\%) respectively. Most commonly prescribed antibiotics were cephalosporines (32.3\%), penicillin (29.5\%) and macrolides (23.2\%). The most common side effect was diarrhea (30.4\%). Whereas high adherence rate was significantly high in the patients without fever, medium adherence rate was detected significantly higher in patients with fever. Percentage of high adherence was significantly high in case the antibiotic was recommended by the family physician.

Conclusions: Antibiotic adherence is quite high in our region. Health literacy levels of the patients are associated with their medication adherence. Antibiotics recommended by the family physicians were used more regularly. Family physicians must behave more carefully about rational drug use, must have a full knowledge of the guides and must meet the requirements of modern medicine.

Keywords:Rational drug use, rational antibiotic use, health literacy, medication adherence, family medicine

Corresponding Author: Ufuk AKKAYA ufuk.akkaya@saglik.gov.tr

Received: December 22, 2021; Accepted: December 29, 2021; Published Online: December 31, 2021

Cite this article as: Akkaya, U. \& Demirci, H. (2021). Factors Affecting The Medication Adherence of the Patients Who Are Prescribed Antibiotics 1(3), 93-107. 


\section{Introduction}

According to the estimation of World Health Organization (WHO), more than half of all medications are prescribed, distributed and sold inconveniently. Nearly half of the patients do not use medications properly and one third of the world population can't reach basic medications (1). Wrong drug use is common in developed countries and in our country both medically and economically. Antibiotics are at the top of these misused drugs.

According to the 2013 data of our Ministry of Health, it is reported that nearly $25.9 \%$ of all health expenses in Turkey were allocated to medication charges and this rate is around $10-15 \%$ in European countries and around $20-40 \%$ in developing countries (2). A high share is allocated to medication expenses in our country, among the reasons of this situation we can list the following causes; therapeutic medicine applications in the forefront, undeveloped preventive medicine applications, inattention of rational drug use, external dependence in pharmaceutical industry, inadequacy of health literacy $(\mathrm{HL})$ rate, excess use of antibiotics.

Antibiotics are used in treatment of human and animal health, animal feeds and plants worldwide. Antibiotics are among the most frequently used medications in the world and in our country. Despite the introduction of medication tracking system and prohibition of nonprescription antibiotic sales in our country in recent years, antibiotics are still in the first rank among the drugs sold (3). Antibiotics consumed unconsciously are the most important elements of drug wastage in our country. When this wastage is considered together with developing antibiotic resistance and its economic cost effect, importance of Rational Antibiotic Use (RAU) increases.
Health literacy level is critical in RAU. As antibiotics are technological products of great importance in preventing individual and social infection diseases and fighting against these diseases, rational use of this valuable source is essential in terms of public health (5). There are several reasons in irrational antibiotic use such as lack of socio-cultural, economic and regulatory health policies together with lack of education as well as insufficiency of inter-sector cooperation. These reasons affect each other and the problems become more complicated (6). Patients request antibiotics redundantly from the physicians and physicians can prescribe antibiotics due to time constraints and pressure. Misdiagnosis, antibiotics used in low dose, short time and period increase the antibiotic resistance in bacteria. In this study, our aim is to investigate the factors affecting antibiotic adherence of the patients who are prescribed antibiotics. In the literature, importance of RAU is increasing day by day with bacteria resistance problem and with its economic and social aspect.

In this study, our aim is to investigate the factors affecting antibiotic adherence of the patients who are prescribed antibiotics.

\section{METHODS}

The dissertation named "Factors affecting the medication adherence of the patients who are prescribed antibiotics" was approved by the Clinical Research Ethics Committee of Bursa Yuksek Ihtisas Training and Research Hospital, University of Health Sciences, with the resolution and approval dated 29.08.2018, no2011-KAEK-25 2018/08-09.

This research was planned as a monocenter, descriptive, observational study. This study was performed between 01.10.2018-30.09.2019. Before being included in the study, each participant was informed about the aim of the study and they were 
asked to sign the volunteer consent form. In our study, a questionnaire was applied to 353 participants through face-to-face interviews. Socio-demographic data form configured by us, Morisky Medication Adherence Scale and short form of European Health Literacy Scale were used to collect data in the study. Face-to-face interviews were conducted with the participants of the study and questions in the questionnaires were addressed to them, later, on the day of the end of antibiotic use, the remaining questions about drug adherence were asked to the participants face-to-face or via telephone.

Patients between age 18-75, registered to Bursa Nilufer 23 Nisan Family Health Center and who were prescribed antibiotics by 4 Family Physicians working in this institution and single-diagnosed patients between age 18-75, registered to Family Health Center but who were recommended to use antibiotics by the physicians in health institutions other than those in FHC (specialist physicians, dentist, emergency physicians working in hospital etc.) were included in this study.

The first part of the questionnaire consists of questions about socio-demographic information (age, gender, profession, marital status, education level, income level) and medical status of the patient (chronic diseases, complaints, time of complaints, whether or not he/she took medications for the complaints, diagnosis, who recommended the antibiotic, name of the antibiotic, dosage, recommended time of use, use of administration, number of days to use the antibiotic, side effects, type of side effects, number of medications used for chronic disease if exists, number of labor lost days, whether or not he/she used the antibiotic for a short time, if yes number of lacking days and reason) and it is attached.

Morisky Medication Adherence Scale: this scale was developed by Morisky, Gren and Levine (1986) with the aim of evaluating the medication adherence of the individuals with chronic disease in a short and accurate way (7). Following questions which were adapted to antibiotic use were posed to the participants about their antibiotic use adherence and their Morisky adherence statuses were grouped in accordance with their scores. This is a self-report consisting of four questions. Turkish validity and reliability study of the scale was performed by Bahar et al.(8).

Short Version of European Health Literacy Scale: Short version of European health literacy was used in our study (9). 16 questions with five choices as "very difficult, fairly difficult, fairly easy, very easy, I don't know" were asked to the participants to measure their HL levels. These choices were scored as; very difficult 1 point, fairly difficult 2 points, fairly easy 3 points, very easy 4 points and I don't know 0 point. The results were grouped in 4 levels according to the total scores as; inadequate $\mathrm{HL}$, problematic $\mathrm{HL}$, sufficient $\mathrm{HL}$ and excellent HL. Turkish validity and reliability study of the scale was performed by Emiral et al. (10).

Statistical Analysis of the Data: Data achieved were analyzed with SPSS Statistical Package $\AA 22.0$ program. In all statistical analysis $\mathrm{p}<0.05$ was accepted as significance level and the relationships were evaluated within $95 \%$ confidence interval. Descriptive data of the study group were expressed with number and percentage for distribution of categorical variables and with mean, standard deviation, median, minimum and maximum for continuous variables. Conformity to normal distribution was checked with Kolmogorov Smirnov and Shapiro Wilk tests. Relationship between categorical dependent and independent variables was assessed with chisquare test and Fisher-Freeman-Halton tests and relationship between numerical and categorical variables were assessed with Kruskal Wallis tests. Bonferroni correction was applied in post-hoc analysis. 


\section{RESULTS}

General characteristics of the participants are given in Table1. Mean age was 40.83 and $68.0 \%$ of the participants were female. $55.2 \%$ of the cases were bachelor's degree.

Table1. Distribution according to socio-demographic features

\begin{tabular}{|c|c|c|c|c|c|}
\hline & & \multicolumn{2}{|c|}{ Number of participants } & \multicolumn{2}{|l|}{$\%$} \\
\hline \multirow{2}{*}{ Gender } & Female & \multicolumn{2}{|l|}{240} & \multicolumn{2}{|l|}{68.0} \\
\hline & Male & \multicolumn{2}{|l|}{113} & \multicolumn{2}{|l|}{32.0} \\
\hline \multirow{3}{*}{ Income } & Low & \multicolumn{2}{|l|}{5} & \multicolumn{2}{|l|}{1.4} \\
\hline & Medium & \multicolumn{2}{|l|}{233} & \multicolumn{2}{|l|}{66.0} \\
\hline & High & \multicolumn{2}{|l|}{115} & \multicolumn{2}{|l|}{32.6} \\
\hline \multirow{2}{*}{ Marital Status } & Single & \multicolumn{2}{|l|}{62} & \multicolumn{2}{|l|}{17.6} \\
\hline & Married & \multicolumn{2}{|l|}{291} & \multicolumn{2}{|l|}{82.4} \\
\hline \multirow{7}{*}{ Profession } & Unemployed & \multicolumn{2}{|l|}{4} & \multicolumn{2}{|l|}{1.1} \\
\hline & Housewife & \multicolumn{2}{|l|}{89} & \multicolumn{2}{|l|}{25.2} \\
\hline & Staff & \multicolumn{2}{|l|}{80} & \multicolumn{2}{|l|}{22.7} \\
\hline & Retired & \multicolumn{2}{|l|}{38} & \multicolumn{2}{|l|}{10.8} \\
\hline & Student & \multicolumn{2}{|l|}{20} & \multicolumn{2}{|l|}{5.7} \\
\hline & Worker & \multicolumn{2}{|l|}{93} & \multicolumn{2}{|l|}{26.3} \\
\hline & Craftsman & \multicolumn{2}{|l|}{29} & \multicolumn{2}{|l|}{8.2} \\
\hline & Illiterate & \multicolumn{2}{|l|}{2} & 0.6 & \\
\hline & Primary school & 34 & & 9.6 & \\
\hline Education & Secondary school & 26 & & 7.4 & \\
\hline & High school & 96 & & 27.2 & \\
\hline & University & 195 & & 55.2 & \\
\hline Age & Mean & $\begin{array}{l}\text { Standard } \\
\text { Deviation }\end{array}$ & Median & Minimum & Maximum \\
\hline & 40.83 & 12.79 & 39.00 & 18.00 & 75.00 \\
\hline
\end{tabular}

Medication adherence was detected significantly higher in the participants with high HL level (Table2). 
Table2. Morisky Medication Adherence and European Health Literacy Scale correlations

\begin{tabular}{|l|l|}
\hline Correlation coefficient & -0.156 \\
\hline p value & $\mathbf{0 . 0 0 3 *}$ \\
\hline
\end{tabular}

*Spearman correlation analysis

The disease for which antibiotics were most frequently prescribed was upper respiratory infection (32.3\%). It was followed by lower respiratory infections (23.5\%), acute sinusitis (13.0\%) and urinary tract infections (7.6\%) respectively (Figure1).

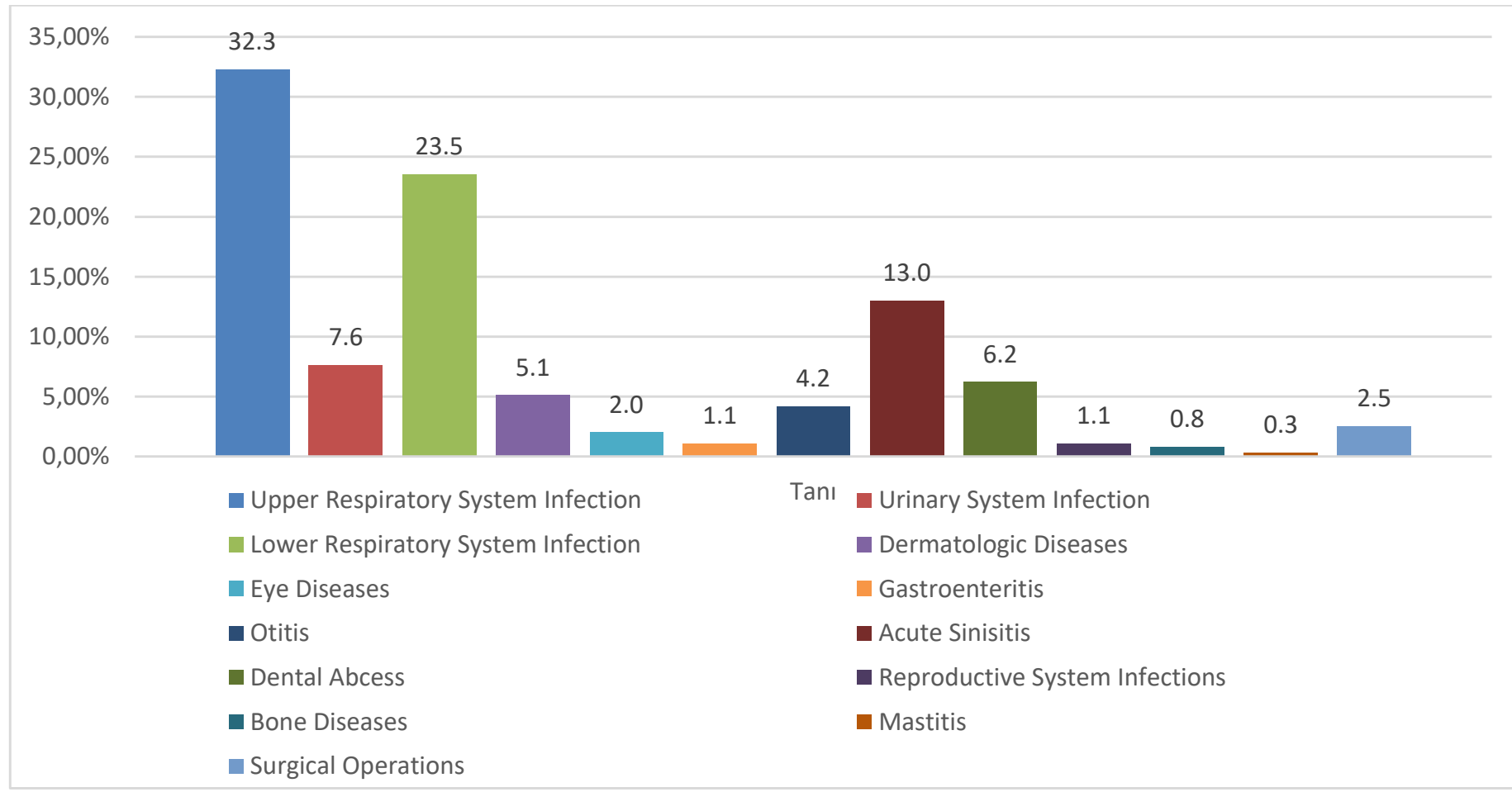

Figure1. Case distribution according to diagnosis

Most commonly prescribed antibiotics were Cephalosporines (32.3\%), Penicillin (29.5\%) and Macrolides (23.2\%) (Figure2). 



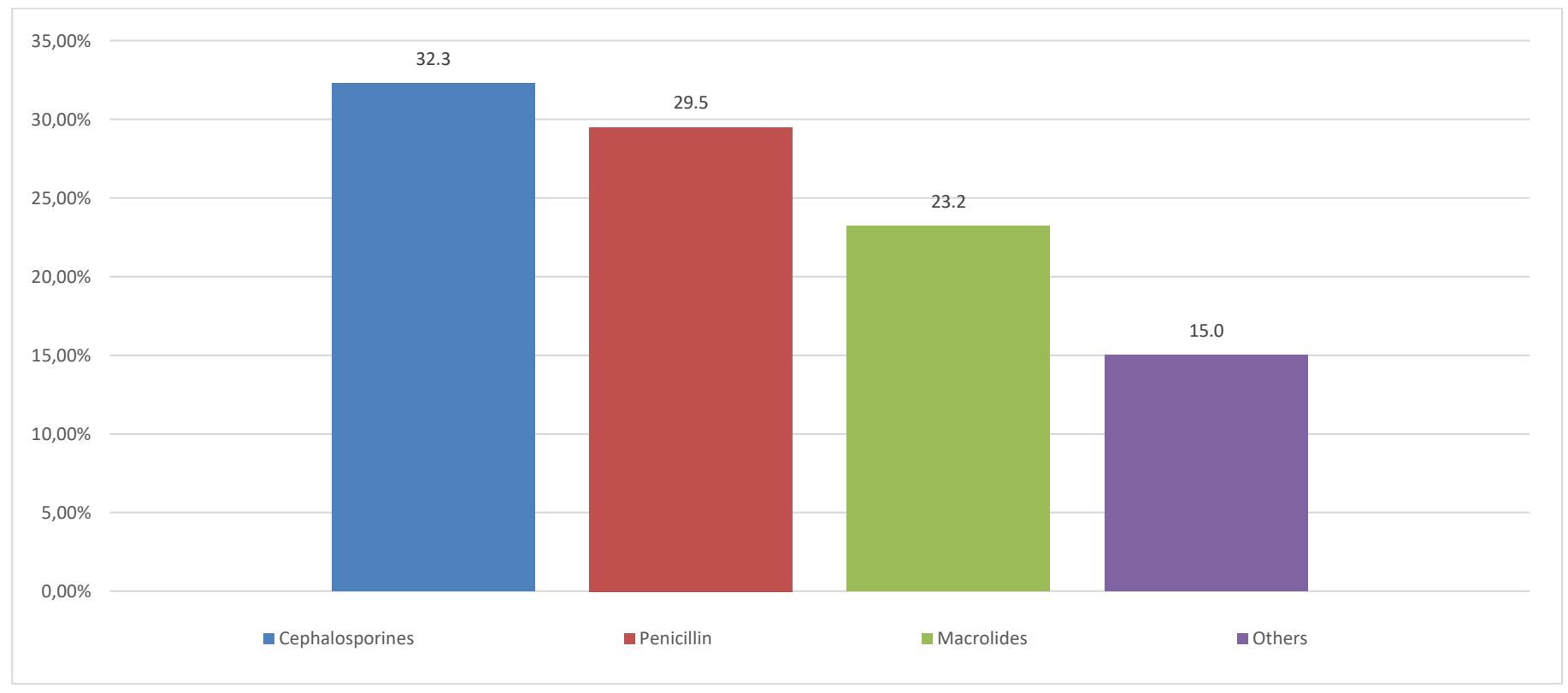

Figure2. Distribution of the antibiotics used

Most prevalent side effect was gastrointestinal complaints (Figure 3). It was followed by itchy skin and allergic reactions.

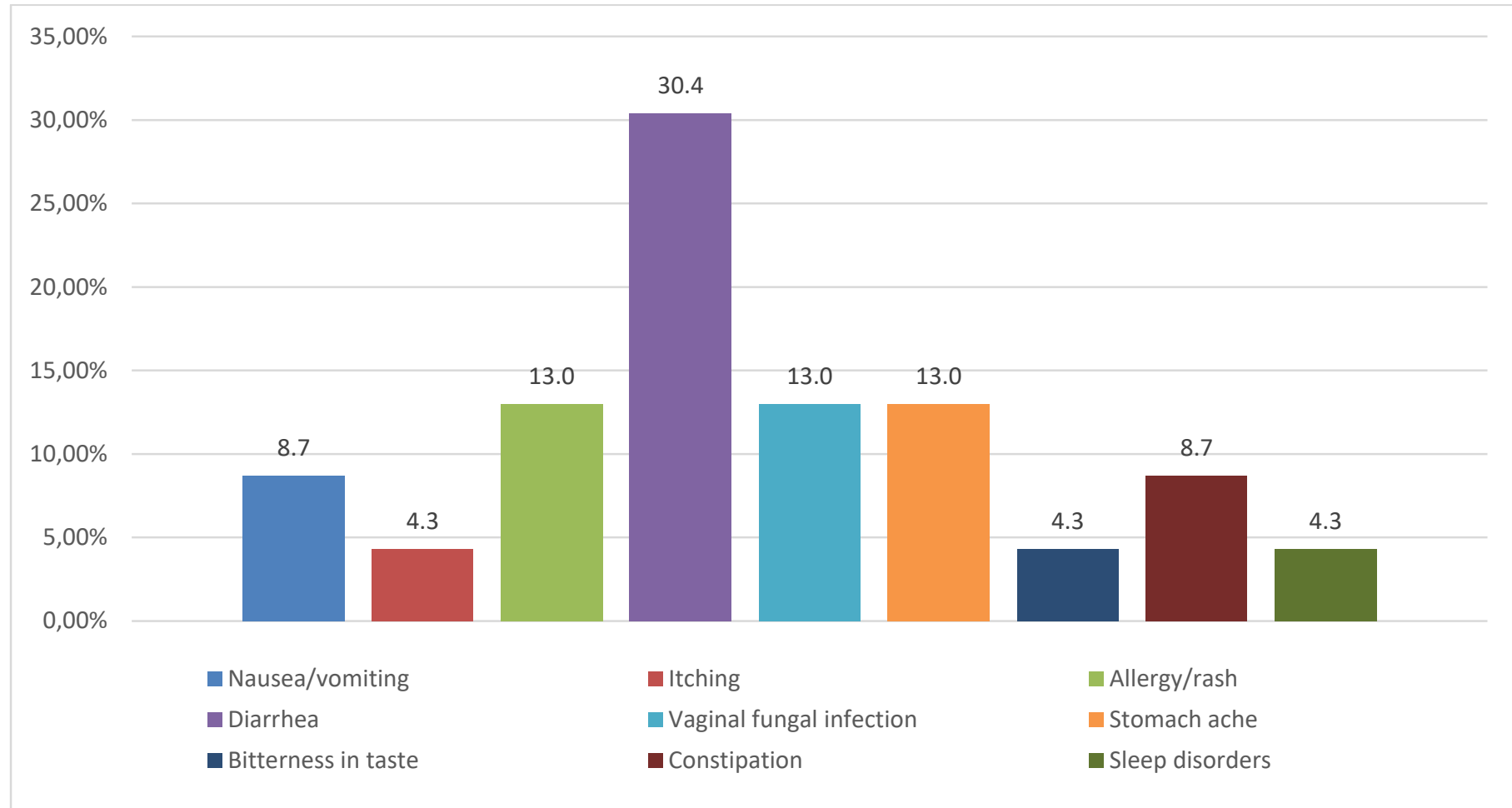

Figure3. Distribution according to side effects

Whereas high adherence rate was significantly high in the patients without fever, medium adherence rate was detected significantly higher in patients with fever (Table 3). Percentage of high adherence was 
significantly high in case the antibiotics were recommended by the family physician (Table 3 and Figure 4)

Table3. Disease and antibiotic categories and adherence scale categories

\begin{tabular}{|c|c|c|c|c|c|c|c|c|}
\hline & & Med & on Adr & nce & & & & \\
\hline & & High & & Me & & Lor & & \\
\hline & & n & $\%$ & n & $\%$ & $n$ & $\%$ & p-value \\
\hline & No & 188 & 73.2 & 58 & 22.6 & 11 & 4.3 & \\
\hline Chronic disease & & & & & & & & $0.731^{*}$ \\
\hline & Yes & 74 & 77.1 & 19 & 19.8 & 3 & 3.1 & \\
\hline & No & 138 & 74.6 & 42 & 22.7 & 5 & 2.7 & \\
\hline Headache & & & & & & & & $0.425^{*}$ \\
\hline & Yes & 124 & 73.8 & 35 & 20.8 & 9 & 5.4 & \\
\hline & No & 170 & 77.6 & 41 & 18.7 & 8 & 3.7 & \\
\hline Nasal flow & & & & & & & & $0.168 *$ \\
\hline & Yes & 92 & 68.7 & 36 & 26.9 & 6 & 4.5 & \\
\hline & No & 156 & 77.2 & 40 & 19.8 & 6 & 3.0 & \\
\hline Nasal obstruction & & & & & & & & $0.268 *$ \\
\hline & Yes & 106 & 70.2 & 37 & 24.5 & 8 & 5.3 & \\
\hline & No & 169 & 75.8 & 46 & 20.6 & 8 & 3.6 & \\
\hline Sneezing & & & & & & & & $0.668^{*}$ \\
\hline & Yes & 93 & 71.5 & 31 & 23.8 & 6 & 4.6 & \\
\hline & No & 185 & 73.4 & 56 & 22.2 & 11 & 4.4 & \\
\hline Swollen tonsils & & & & & & & & $0.779 *$ \\
\hline & Yes & 77 & 76.2 & 21 & 20.8 & 3 & 3.0 & \\
\hline & No & 252 & 74.6 & 73 & 21.6 & 13 & 3.8 & \\
\hline Cryptic Tonsillitis & & & & & & & & $0.409^{\wedge}$ \\
\hline & Yes & 10 & 66.7 & 4 & 26.7 & 1 & 6.7 & \\
\hline & No & 124 & 75.2 & 35 & 21.2 & 6 & 3.6 & \\
\hline Cough & & & & & & & & 0.917* \\
\hline & Yes & 138 & 73.4 & 42 & 22.3 & 8 & 4.3 & \\
\hline & No & 259 & 74.2 & 76 & 21.8 & 14 & 4.0 & \\
\hline Lymphadenopathy & Yes & 3 & 75.0 & 1 & 25.0 & 0 & 0.0 & \\
\hline & No & 155 & 73.8 & 50 & 23.8 & 5 & 2.4 & \\
\hline Drug usage & & & & & & & & $0.120 *$ \\
\hline & Yes & 107 & 74.8 & 27 & 18.9 & 9 & 6.3 & \\
\hline Fever & No & 177 & 78.3 & 40 & 17.7 & 9 & 4.0 & 0.043* \\
\hline
\end{tabular}




\begin{tabular}{|c|c|c|c|c|c|c|c|c|}
\hline & Yes & 85 & 66.9 & 37 & 29.1 & 5 & 3.9 & \\
\hline \multirow{5}{*}{ Antibiotics } & Cephalosporines & 79 & 69.3 & 29 & 25.4 & 6 & 5.3 & \multirow{5}{*}{$0.800^{\wedge}$} \\
\hline & Penicillin & 82 & 78.8 & 19 & 18.3 & 3 & 2.9 & \\
\hline & Quinolone & 21 & 72.4 & 8 & 27.6 & 0 & 0.0 & \\
\hline & Macrolides & 62 & 75.6 & 16 & 19.5 & 4 & 4.9 & \\
\hline & Other & 18 & 75.0 & 5 & 20.8 & 1 & 4.2 & \\
\hline \multirow{3}{*}{ Penicillin } & No & 180 & 72.3 & 58 & 23.3 & 11 & 4.4 & \multirow{3}{*}{$0.426 *$} \\
\hline & & & & & & & & \\
\hline & Yes & 82 & 78.8 & 19 & 18.3 & 3 & 2.9 & \\
\hline \multirow{2}{*}{$\begin{array}{l}\text { Who prescribed } \\
\text { antibiotic? }\end{array}$} & $e^{\text {Family physician }}$ & 199 & 77.1 & 53 & 20.5 & 6 & 2.3 & \multirow{2}{*}{$0.016 *$} \\
\hline & Other physicians & 63 & 66.3 & 24 & 25.3 & 8 & 8.4 & \\
\hline \multirow{3}{*}{ Dosage } & 1.00 & 57 & 73.1 & 16 & 20.5 & 5 & 6.4 & \multirow{3}{*}{$0.743^{\wedge}$} \\
\hline & 2.00 & 183 & 74.1 & 55 & 22.3 & 9 & 3.6 & \\
\hline & 3.00 & 22 & 78.6 & 6 & 21.4 & 0 & 0.0 & \\
\hline \multirow{5}{*}{ Routes of administration } & Oral & 215 & 75.4 & 60 & 21.1 & 10 & 3.5 & \multirow{5}{*}{$0.352^{\wedge}$} \\
\hline & Intramuscular & 35 & 67.3 & 14 & 26.9 & 3 & 5.8 & \\
\hline & Dermal & 5 & 71.4 & 2 & 28.6 & 0 & 0.0 & \\
\hline & Ophthalmic & 6 & 85.7 & 0 & 0.0 & 1 & 14.3 & \\
\hline & External ear & 1 & 50.0 & 1 & 50.0 & 0 & 0.0 & \\
\hline \multirow{3}{*}{ Routes of administration } & Oral & 215 & 75.4 & 60 & 21.1 & 10 & 3.5 & \multirow{3}{*}{$0.435^{*}$} \\
\hline & & & & & & & & \\
\hline & IM & 35 & 67.3 & 14 & 26.9 & 3 & 5.8 & \\
\hline \multirow{3}{*}{ Side effects } & No & 246 & 74.5 & 70 & 21.2 & 14 & 4.2 & \multirow{3}{*}{$0.389 *$} \\
\hline & & & & & & & & \\
\hline & Yes & 16 & 69.6 & 7 & 30.4 & 0 & 0.0 & \\
\hline \multirow{3}{*}{ Loss of labor } & No & 217 & 74.6 & 63 & 21.6 & 11 & 3.8 & \multirow{3}{*}{$0.908^{*}$} \\
\hline & & & & & & & & \\
\hline & Yes & 45 & 72.6 & 14 & 22.6 & 3 & 4.8 & \\
\hline \multirow{2}{*}{$\begin{array}{l}\text { Using in short time and } \\
\text { dose }\end{array}$} & & 254 & 96.9 & 65 & 84.4 & 10 & 71.4 & \multirow{2}{*}{$<0.001 *$} \\
\hline & Yes & 8 & 3.1 & 12 & 15.6 & 4 & 28.6 & \\
\hline
\end{tabular}

${ }^{*}$ Chi-square test, ^Fisher Freeman Halton; n: number of participants. 


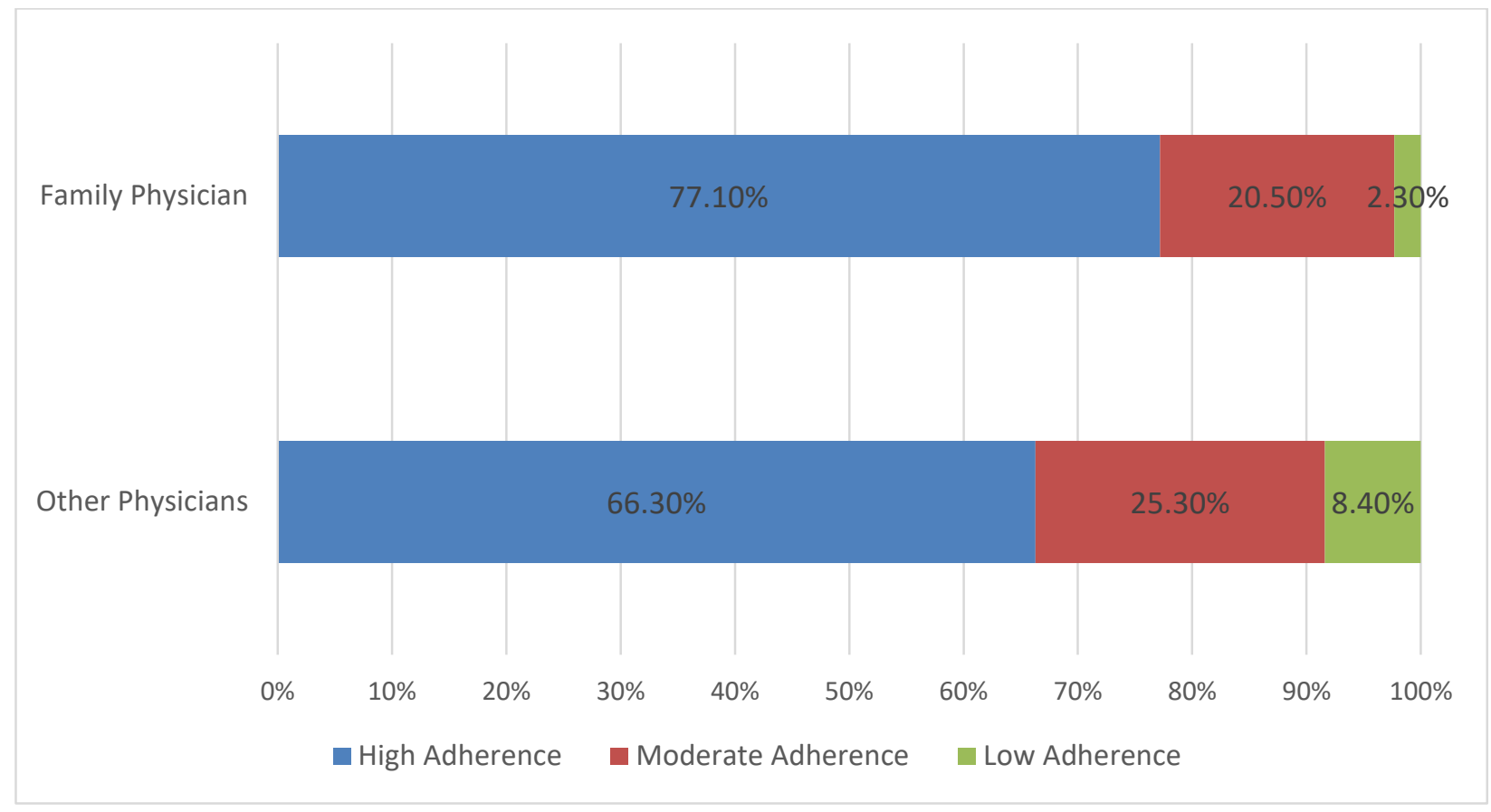

Figure4. Morisky scale categories according to the physician who recommends the antibiotic

Health literacy was similar in terms of gender, income, marital status and profession groups. Excellent $\mathrm{HL}$ rate of the primary school graduates was significantly lower than high school and university graduates.

Table4. European Health Literacy Scale Categories according to socio-demographic feature

\begin{tabular}{|c|c|c|c|c|c|c|c|c|}
\hline & & Health L & erac) & & & & & \\
\hline & & Problem & & Sufficien & & Excellen & & \\
\hline & & Number & $\%$ & Number & $\%$ & Number & $\%$ & p-value \\
\hline & Female & 1 & 0.4 & 81 & 33.8 & 158 & 65.8 & \\
\hline Gender & Male & 3 & 2.7 & 35 & 31.0 & 75 & 66.4 & $0.104 \pi$ \\
\hline & Low & 0 & 0.0 & 4 & 80.0 & 1 & 20.0 & \\
\hline Income & Medium & 3 & 1.3 & 78 & 33.5 & 152 & 65.2 & $0.175^{\wedge}$ \\
\hline & High & 1 & 0.9 & 34 & 29.6 & 80 & 69.6 & \\
\hline Marital & Single & 1 & 1.6 & 20 & 32.3 & 41 & 66.1 & \\
\hline status & Married & 3 & 1.0 & 96 & 33.0 & 192 & 66.0 & \\
\hline
\end{tabular}




\begin{tabular}{|c|c|c|c|c|c|c|c|c|}
\hline \multirow{7}{*}{ Profession } & Unemployed & 0 & 0.0 & 2 & 50.0 & 2 & 50.0 & \multirow{7}{*}{-} \\
\hline & Housewife & 0 & 0.0 & 39 & 43.8 & 50 & 56.2 & \\
\hline & Staff & 0 & 0.0 & 19 & 23.8 & 61 & 76.3 & \\
\hline & Retired & 1 & 2.6 & 11 & 28.9 & 26 & 68.4 & \\
\hline & Student & 1 & 5.0 & 7 & 35.0 & 12 & 60.0 & \\
\hline & Worker & 1 & 1.1 & 27 & 29.0 & 65 & 69.9 & \\
\hline & Craftsman & 1 & 3.4 & 11 & 37.9 & 17 & 58.6 & \\
\hline \multirow{5}{*}{ Education } & Illiterate & 0 & 0.0 & 2 & 100.0 & 0 & 0.0 & \multirow{5}{*}{$<0.001^{\wedge}$} \\
\hline & Primary School & 0 & 0.0 & 25 & 73.5 & 9 & 26.5 & \\
\hline & Secondary School & 1 & 3.8 & 10 & 38.5 & 15 & 57.7 & \\
\hline & High School & 3 & 3.1 & 34 & 35.4 & 59 & 61.5 & \\
\hline & University & 0 & 0.0 & 45 & 23.1 & 150 & 76.9 & \\
\hline
\end{tabular}

Rate of swollen tonsils was higher in the group with excellent HL among the participants (Table5). HL level was higher in those with daily dose of 3.
Correlation of Morisky Scale and European Health Literacy Scale numerical values was calculated as $83.8 \%$.

Table5. European Health Literacy Scale and disease and patient characteristics

\begin{tabular}{|c|c|c|c|c|c|c|c|c|}
\hline & & & itera & & & & & \\
\hline & & & atic & Su & & Exce & & \\
\hline & & & Perc & $\mathrm{eNu}$ & Perc & eNum & rPerc & ep-value \\
\hline & No & 4 & 1.6 & 82 & 31.9 & 171 & 66.5 & \\
\hline Chronic disease & & & & & & & & $0.599^{\wedge}$ \\
\hline & Yes & 0 & 0.0 & 34 & 35.4 & 62 & 64.6 & \\
\hline & No & 0 & 0.0 & 60 & 32.4 & 125 & 67.6 & \\
\hline Headache & & & & & & & & $0.122^{\wedge}$ \\
\hline & Yes & 4 & 2.4 & 56 & 33.3 & 108 & 64.3 & \\
\hline & No & 1 & 0.5 & 78 & 35.6 & 140 & 63.9 & \\
\hline Nasal flow & & & & & & & & $0.114^{\wedge}$ \\
\hline & Yes & 3 & 2.2 & 38 & 28.4 & 93 & 69.4 & \\
\hline
\end{tabular}




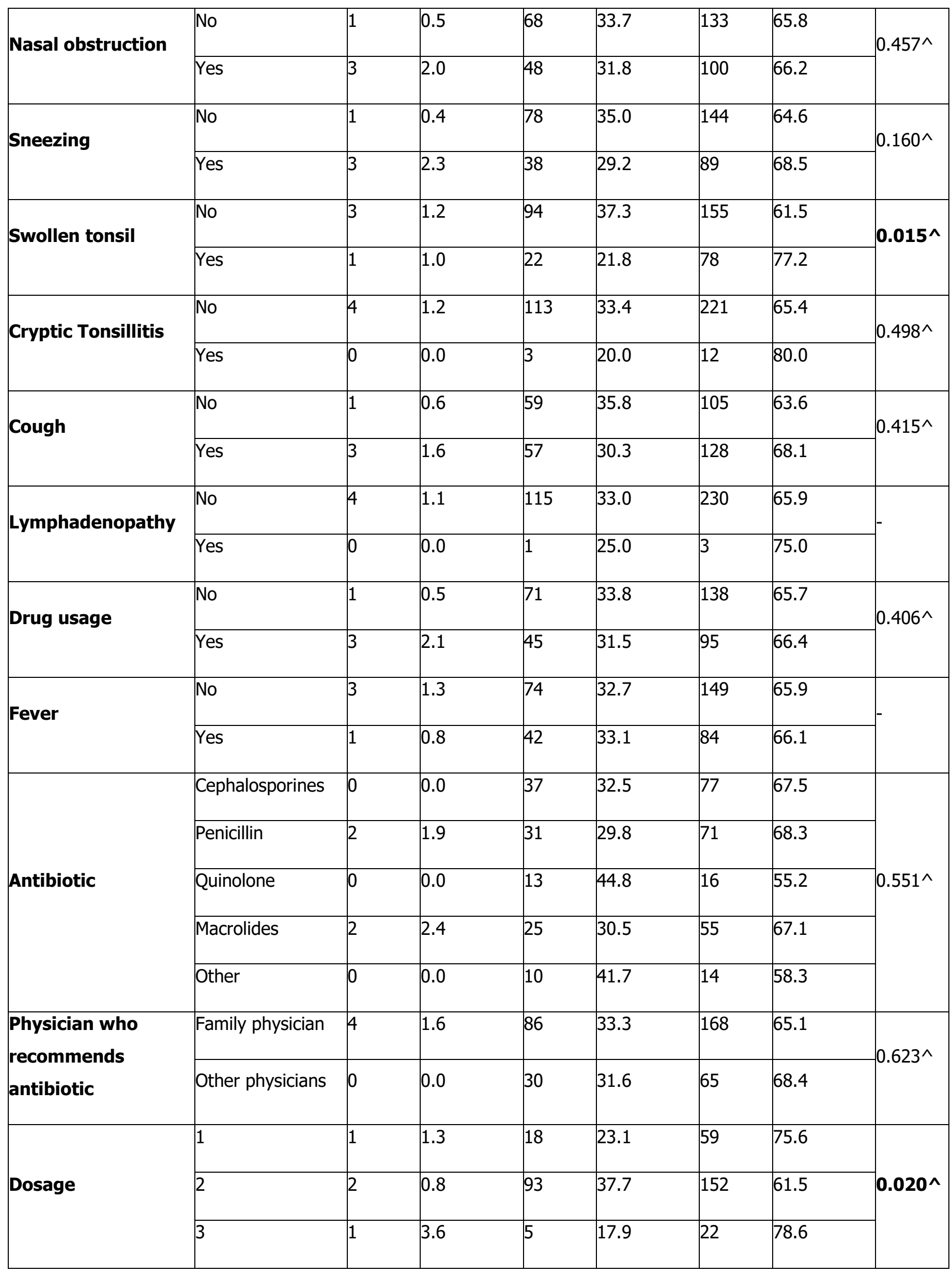




\begin{tabular}{|c|c|c|c|c|c|c|c|c|}
\hline \multirow{6}{*}{$\begin{array}{l}\text { Use } \\
\text { administration }\end{array}$} & Oral & 4 & 1.4 & 96 & 33.7 & 185 & 64.9 & \multirow{6}{*}{$0.070^{\wedge}$} \\
\hline & Intramuscular & 0 & 0.0 & 13 & 25.0 & 39 & 75.0 & \\
\hline & & & & & & & & \\
\hline & Dermal & 0 & 0.0 & 6 & 85.7 & 1 & 14.3 & \\
\hline & Ophthalmic & 0 & 0.0 & 1 & 14.3 & 6 & 85.7 & \\
\hline & External ear & 0 & 0.0 & 0 & 0.0 & 2 & 100.0 & \\
\hline \multirow{2}{*}{$\begin{array}{l}\text { Use } \\
\text { administration }\end{array}$} & foral & 4 & 1.4 & 96 & 33.7 & 185 & 64.9 & \multirow{2}{*}{$0.371^{\wedge}$} \\
\hline & Intramuscular & 0 & 0.0 & 13 & 25.0 & 39 & 75.0 & \\
\hline \multirow{3}{*}{ Side effect } & No & 4 & 1.2 & 107 & 32.4 & 219 & 66.4 & \multirow{3}{*}{$0.731^{\wedge}$} \\
\hline & & & & & & & & \\
\hline & Yes & 0 & 0.0 & 9 & 39.1 & 14 & 60.9 & \\
\hline \multirow{3}{*}{ Loss of labor } & No & 4 & 1.4 & 94 & 32.3 & 193 & 66.3 & \multirow{3}{*}{$0.893^{\wedge}$} \\
\hline & & & & & & & & \\
\hline & Yes & 0 & 0.0 & 22 & 35.5 & 40 & 64.5 & \\
\hline \multirow{2}{*}{$\begin{array}{l}\text { Using in short time } \\
\text { and dose }\end{array}$} & No & 4 & 1.2 & 106 & 32.2 & 219 & 66.6 & \multirow{2}{*}{$0.529 \wedge$} \\
\hline & Yes & 0 & 0.0 & 10 & 41.7 & 14 & 58.3 & \\
\hline
\end{tabular}

\section{DISCUSSION}

As a result of this study, medication adherence was detected significantly higher in the participants with high HL. The disease for which antibiotics were most frequently prescribed was upper respiratory infection $(32.3 \%)$. It was followed by lower respiratory infections (23.5\%), acute sinusitis (13.0\%) and urinary tract infections $(7.6 \%)$ respectively. Most commonly prescribed antibiotics were Cephalosporines (32.3\%), Penicillin (29.5\%) and Macrolides (23.2\%). The most common side effect was diarrhea (30.4\%). Rate of high adherence was significantly high in the patients without fever. Medication dose and swollen tonsil was associated with $\mathrm{HL}$. High adherence rate was significantly high in case the antibiotic was prescribed by the family physician.

According to our study, most commonly prescribed antibiotics were Cephalosporines (32.3\%), Penicillin
(29.5\%), Macrolides (23.2\%) and Quinolones (8.2\%) and this result was inconsistent with the literature. In the study called "Rational prescription of antimicrobials among family physicians and specialists: attitudes and demands" conducted by Çöplü et al. they were ranked as Penicillin (67.8\%), Cephalosporines (36.3\%), Macrolides (13.8\%), Quinolones (9.59\%) (11). In this current study, it was detected that physicians didn't use "Ministry of Health Diagnostic and Therapeutic Guide for Primary Care" at a high rate of $56 \%$ while prescribing antibiotics. In another study conducted in a health center in Mersin, it was reported that the most common diagnosis on patients was acute respiratory system infection (32.4\%) and Penicillin (56.1\%), Macrolides (21.9\%) and Cephalosporines (11.5\%) were the antibiotics prescribed (12). On the other hand, in the study performed by Döşler et al. in 2014 in Istanbul called "RAU: A sample from İstanbul", physicians participating in the study indicated that they 
preferred Penicillin around $60 \%$ and Cephalosporines around $35 \%$ (13). This ranking wasn't compatible with our study.

Allergic reactions developing against antibiotics are the most known and most fearsome side effects of this group of medications (14). Allergic reactions developing with the use of antibiotics can be seen in different forms from simple rash to anaphylaxis. Another side effect is skin reaction. Various types of exanthematous skin reactions can occur and it must be well-assessed in which circumstances the antibiotic must be discontinued. Many antibiotics can cause hepatotoxicity buta level of toxicity in which the therapy must be terminated is not very common. The most common gastrointestinal side effect is diarrhea (14). Nephrotoxicity, hematologic side effects, cardiac side effects, autotoxicity, neurotoxicity, musculoskeletal side effects andelectrolyte disorders are the other side effects.

In our study, 329 out of 353 patients (93.2\%) used the antibiotics within recommended time and dose, 24 of them (6.8\%) showed nonadherence. Number of patients in our study with nonadherence was significantly lower than other studies. The region of our study has a high level of income, education and HL. In a study conducted by Kukula in 2018, it was reported that, $34.6 \%$ of the participants used the antibiotics until they are finished, $26.2 \%$ of them used the antibiotic in the length of time prescribed by the physician (15). In that study, antibiotic adherence was found much lower than our study. The reason of this can be the high mean age in our sampling. Shorter recovery time of the young people can be a reason of this.

High adherence rate was significantly high in the participants without antibiotic use in insufficient time and dose andlow adherence rate was significantly high in those with antibiotic use in insufficient time and dose. In a study conducted by Yilmaz et al. in Ankara in 2016, it was found out that $\mathrm{HL}$ and medication knowledge affected medication adherence, as well as socio-economic factors (16). In that study, it was identified that drug nonadherence was mostly among diabetes-diagnosed patients. Patients' beliefs can play a role in their medication adherence. In the same study, it was detected that belief on the necessity of the drugs had a positive effect on medication adherence of old individuals with chronic diseases and belief on excess use had a negative effect (16).

Asa result of our study, it was detected that medication adherence was significantly higher in the participants with high $\mathrm{HL}$. No cases with inadequate $\mathrm{HL}$ were seen. There were $4(1.1 \%)$ problematic $\mathrm{HL}, 116$ (32.9\%) sufficient $\mathrm{HL}$ and $233(66.0 \%)$ excellent $\mathrm{HL}$. In a sectional study conducted on in-patients under treatment, it was found out that awareness of the participants about Rational Drug Use and their HL level were inadequate (17). HL levels of the participants of our research were high. Region of our study had a high education and income level; briefly it was a region with features which positively contributed to HL level. In a study, it was detected that $\mathrm{HL}$ level of the patients applying to family physicians tend to rise with increase in education and income level (18). HL level was found higher in those who covered medicine expenses, inadequate and problematic $\mathrm{HL}$ was found higher in student group (18). It is observed in our study that high $\mathrm{HL}$ level of participants has a positive impact on antibiotic adherence.

High medication adherence has been reported in the studies conducted in primary care with chronic hypertension and diabetes cases $(19,20)$. It was also detected that antibiotics prescribed in primary care units where continuous care was received were used more regularly by patients. This situation can be an indicator the patients' trust on their family physicians 
and it can also be associated with the severity of their complaints about which they apply to their family physicians. Our study results might have been negatively affected because questionnaires were filled in primary care units. In addition, the fact that cases without fever quit their medication more quickly can also be related to the severity of the disease they experience. Fever can be a stimulant directing the patients towards medication.

As a conclusion, antibiotic adherence is quite high in our region. HL levels of the patients are associated with their drug adherence levels. High education level in our region enabled us to study with a more conscious patient portfolio. Antibiotics recommended by the family physicians were used more regularly. Family physicians must behave more carefully about rational drug use, must have a full knowledge of the guides and must meet the requirements of modern medicine.

\section{CONFLICT OF INTEREST}

The authors declare that there is no conflict of interest.

\section{REFERENCES}

1. Aydin B, Gelal A. Akılcı İlaç Kullanımı: Yaygınlaştııılması ve Tıp Eğitiminin Rolü. DEÜ Tıp Fakültesi Dergisi. 2012; 26: 57 -63.

2. Altindis S. Akılcı İlaç Kullanımına Sistematik Bir Bakış Journal of BSHR 2017; 1: 34-38.

3. Bozdemir E, Filiz M. Türkiye'de akılcı ilaç kullanımı ile ilgili bilgi, tutum ve davranış belirlemeye yönelik yapılan çalışmaların sistematik derlemesi. Dicle Üniversitesi Sosyal Bilimler Enstitüsü Dergisi. 2021; (27): 92-105.

4. TÜİK, A. Y. A. (2012). Türkiye İstatistik Kurumu Matbaası.

5. WHO, 1998. World Health Organization Health Promotion Glossary. Geneva.

6. Ekenler S, Kocoglu D. Bireylerin Akılcı İlaç Kullanımıyla İlgili Bilgi ve Uygulamaları. Hacettepe Üniversitesi Hemşirelik Fakültesi Dergisi. 2016; 3: 4455.

7. Morisky DE, Green LW, Levine DM. Concurrent and predictive validity of a self-reported measure of medication adherence. Med Care. 1986; 24: 67-74.

8. Bahar G , Sava HA , Ünal A, Sava E , Kaya H , Bahar A . Reliability and validity of the Morisky Medication Adherence Scale for bipolar mood disorder. Anatolian J Psychiatry 2014; 15:141-9 .

9. HLS-EU Consortium . Comparative report of health literacy in eight EU member states. The European health literacy survey HLS-EU. 2012.

10. Emiral, G. O., Aygar, H., Isiktekin, B., Göktas, S., Dagtekin, G., Arslantas, D., \&Unsal, A. Health literacy scale-European union-Q16: a validity and reliability study in turkey. Int. Res. J. Med. Sci. 2018; 6: 1-7.

11. Çöplü N, İlhan MN, Ciliv EF, Şenlik ZB, Ertek M. Aile hekimleri ve uzmanlar arasında

Antimikrobiyallerin akılcı reçetelendirilmesi: tutum ve talepler. Turk Hij Den Biyol Derg. 2014; 71: 19-26.

12. Şaşmaz T, Buğdaycı R, Kurt AÖ, Tezcan H. Mersin'de bir merkez Sağlık Ocağında Akut

SolunumYolu İnfeksiyonları için Reçete Edilen Antibiyotiklerin İncelenmesi, Mersin Üniversitesi Tıp Fakültesi Derg. 2002; 3: 185-190.

13. Döşler S, Ulusoy A. AkılcıAntibiyotikKullanımı: İstanbul'danBirÖrnekTurkiyeKlinikleri ] Pharm Sci 2014;3:55-64.

14. Öncü S. Antibiyotiklerin İstenmeyen Etkilerinin İzlemi Yönetimi. ANKEM Derg 2013; 27: 82-84. 
15. Kukula O. Tıp Fakültesi Öğrencilerinin Antibiyotik Kullanımının Değerlendirilmesi Ortadogu Tip Dergisi. 2019; 11: 239-243.

16. Yilmaz F, Colak M.Y, Kronik Hastalığı Olan Yaşlı Bireylerde İlaç İnancının ve Tedaviye

Uyumun Değerlendirilmesi. 2018; 3: 113-121.

17. Incesu E. Akılcı ilaç kullanımında sağlık okuryazarlığı: Bir kamu hastanesi yatan hastaları üzerine bir araştırma. Sağılı Akademisyenleri Dergisi. 2017; 4: 28-38.

18. Ozdemir Y. Aile Sağlığı Merkezlerine Başvuran Hastaların Sağlık Okuryazarlık Düzeylerinin
Belirlenmesi: Kahramanmaraş İli Örneği. (Yüksek Lisans Tezi) 2018: 42-68.

19. Natarajan N, Putnam W, Van Aarsen K, Lawson KB, Burge F. Adherence to antihypertensive medications among family practice patients with diabetes mellitus and hypertension. Canadian Family Physician. 2013: 59: 93-100.

20. Natarajan N, Putnam RW, Yip AM, Frail D. Family practice patients' adherence to statin medications. Canadian Family Physician. 2007; 53: 2144-2145. 